Курт А. Рафлауб

Универзитет Браун

kurt_raaflaub@brown.edu
Оригиналан научни рад

примљено: 20. март 2012

прихваћено: 1. октобар 2012

\title{
РАТ ЈЕ ОТАЦ СВЕГА: \\ ПОЛИТИКА РАТА, ИМПЕРИЈЕ И СЛОБОДЕ У ДЕМОКРАТСКОЈ АТИНИ*
}

Сажетак: O Атини V века данас размишљамо као о „златном добу“, добу величине у погледу културе и хуманизма, које карактеришу Партенон, Фидијине скулптуре, Софоклове трагедије, Аристофанове комедије, Тукидидова Историја и настанак Сократове филозофије. Антички извори сугеришу, међутим, да су савременици, за време и после Перикловог доба, „величину“ дефинисали кроз задивљујуће победе у рату, империјалну моћ без преседана, и недостижну слободу - све то захваљујући грађанима подједнако посвећеним, под утицајем моћне грађанске идеологије, непрекидној војној и политичкој доминацији њихове заједнице. Атина је прва грчка држава која је изградила поморско царство и довела принцип демократије до крајњих граница. Царство и демократија су били међусобно повезани; грађани су уживали степен учешћа у политици, моћи и одговорности коме се неће наћи равног током више од два миленијума. А ипак, свега двадесет и пет година након смрти Перикла, изгладнела и исцрпљена Атина је изгубила Пелопонески рат и нашла се на ивици уништења. Овај есеј разматра тензије и противречности, тако пуно значења за наше доба, садржане у атинској политици и идеологијима рата, империје и слободе, као и њихову непосредну повезаност са демократијом.

Кључне речи: Рат у античком свету, класична Атина, Перикле, империјализам, демократија, слобода.

\section{Пролог}

Један од раних грчких филозофа, Хераклит, каже: „Рат је отац свега и свега краљ, једне је показао као богове друге као људе, једне је учинио робовима а друге слободнима.“1 Рат је у људској историји, било директно било посредно, стимулисао

\footnotetext{
* Предавање Курта А. Рафлауба на Филозофском факултету у Новом Саду 8. септембра 2011. године.

${ }^{1}$ Хераклит (позни VI век п.н.е.), фр. 53 Diels-Kranz (прев. М. Сиронић); бр. 212 у Kirk et al. 1983, 193-194; енг. прев. Freeman 1948, 28. Захваљујем се Друштву за античке студије Србије и његовом председнику, професору Ксенији Марицки-Гађански на позиву да говорим пред скупом Друштва у септембру 2011. и
} 
неке од највећих технолошких и културних помака. Тако је било и у античкој Грчкој: без рата не би било Илијаде, не би било Партенона, нити Историја Херодота или Тукидида, и стога можда ни писања о историји какво ми познајемо. ${ }^{2}$ Без рата и ратом стечених царстава не би било, видећемо, ни демократије нити крајњих последица слободе. Човечанство је препуно загонетки. За ову мислим да је крајње интересантна.

Једно од кључних ратних искустава у прошлости били су Персијски ратови: покушаји да се освоји Грчка које су предузели владари Персијског царства које се у то време протезало од Средоземља па све до Индије. Краљ Дарије је претрпео неуспех на Маратону 490. п.н.е., Ксеркс код Саламине и Платеје 480/479. Дајем цитат из представе Персијанщи, трагичког песника Есхила:

Сад у бој крените, о децо хеленска, домају бран'те, спасавајте дечицу и жене и кров боговима очинским и дедовима гроб! Сад за све бијемо бој!

(402-405, прев. М. Н. Ђурић)

Ово је поетски израз „борбеног поклича слободе“ који је отворио битку код Саламине 480. године. Он је разбио тишину раног јутра и запрепастио персијску армаду која је стајала у приправности читаве ноћи, очекујући да удари на грчке бродове за које се мислило да су у бекству. Како је то пренео гласник онима који су са стрепњом ишчекивали вести у персијској престоници Сузи:

\footnotetext{
Тад најпре од Хелена чу се урнебес, к'о нека песма радосна, а с острва од стена оних гласна јека одјекну. Страх освоји ти целу војску персијску, јер превари се...

Из грла персијског јекну одговор, оклевању не беше више времена.
}

(388-392, 406-407, прев. М. Ђурић)

Есхилови Грци певају једним гласом, Персијанци одговарају жамором који подсећа на удар морских таласа; и заиста, на другој страни су посаде свакако узвикивале на много језика. То нас подсећа на Хомерову Илијаду, где се тихо и одлучно наступање Грка у битку супротставља Тројанцима који жаморе попут птица. ${ }^{3}$ Овај контраст има дубље значење и на овом месту: јединство и слободна

\footnotetext{
на великодушном гостопримству. Такође захваљујем свима који су узели учешћа у дискусији на корисним повратним информацијама и професорима Маријани Рицл и Ивану Јордовићу на пријатељству и неуморном напору да ми приближе културну, археолошку и кулинарску ризницу Србије. Облик овог предавања сам оставио претежно неизмењеним и додао само минимум напомена.

${ }^{2}$ Видети, на пр. Cartledge 2001.

${ }^{3}$ Жамор (rhothos): Hall 1999, 136. Тројанци насупрот Ахејаца: Илијада III 8-9; IV 429-438. „Бојни поклич слободе“ је израз позајмљен из наслова McPherson-a 1988.
} 
воља на једној страни, етничко шаренило под јармом тиранина на другој!

Допустите ми да накратко размотрим четири појединости повезане са овом представом. Прво, она је изведена 472, свега седам година након коначне победе Грка. Есхил се лично борио на Маратону и код Саламине. Његов брат је погинуо када је покушао да задржи персијски брод и његова рука је одсечена. Стихови на надгробном споменику овог самог песника наводе његово име, оца, град, додајући: „О његовој племенитој храбрости свето поље маратонско може да сведочи, као и Персијанци дуге косе, који то добро знају.“ Ни речи о поезији којој се тако дубоко дивимо, само о поносном доприносу песника победи његовог града! ${ }^{4}$

Друго, већ трагедија Персијаничи укратко нуди популарно тумачење Персијских ратова. Она наглашава Ксерксову намеру да Хелади наметне ,јарам ропства“ - прихватити га, било би супротно грчкој природи. У сну, краљица-мајка, Атоса, види свог сина како упреже две младе жене у своју кочију. Једна, у персијској ношњи, потчињава се вољно и са поносом. Друга, у грчкој одећи, опире се и преврће кочију, бацајући краља у прашину. Као одговор на Атосино питање о вођи и господару Атињана, хор узвикује: „Робље нису никоме и никоме нису подложни!“‘5 Они на тај начин антиципирају оно што ће постати пословично: Грци су слободни, док су Персијанци и други Азијци потчињени тиранији персијских краљева, својевољно прихватили „ропство.“ Персијски ратови као ратови који су донели очување грчке слободе и одлучујући допринос Атине овом постигнућу: те две чињенице су постале стубови поноса Атине, њене претензије на величину и империјалне идеологије у деценијама које следе.

Као треће, мада драма недвосмислено слави грчки тријумф код Саламине, она, запањујуће, сагледава овај догађај не из перспективе победника већ из угла оних који су изгубили - из персијске престонице Сузе а не из Атине. Ми стрепећи ишчекујемо заједно са персијским старешинама вести о рату; скрхани смо заједно с њима када сазнајемо о катастрофи и губитку толиког броја ваљаних људи и не можемо а да не тугујемо заједно са Ксерксом када он најзад стигне кући, као сломљен човек и (сасвим неисторијски) у прњама, јер је узроковао толико пуно несреће својој земљи - све због претеране амбиције и занемаривања мудрих историјских лекција. Ми - попут атинске публике - схватамо да је згрешио прелазећи границе које су богови поставили - азијске области припадају Персијанцима, европске земље Грцима - и ми, попут Атињана, смо злослутно свесни да, управо у то време, атинске снаге делују на другој обали Егејског мора, успостављајући контролу над западном обалом Анадолије - над једном азијском облашћу. ${ }^{6}$

Као четврто, финансијски покровитељ ове трагедије био је нико други до млади Перикле - који ће ускоро постати највећи атински државник. Од касних четрдесетих година V века био је неоспорни вођа Атине током више од једне

\footnotetext{
${ }^{4}$ Anon. Vita Aesch. 11, прев. J. Herington; Paus. I 14, 5. О Есхиловом брату: Hdt. VI 114.

${ }^{5}$ Јарам ропства: Aesch. Pers. 50; Атосин сан: 181-197. Робље нису никоме: 242.

${ }^{6}$ Ксерксов повратак: ibid. 970 и даље; његова сагрешења: 739 и даље. О политичким обзирима представе, видети Meier 1988, 76-93 (=1993, 63-78); Raaflaub 1988, 284-286.
} 
деценије. Мада је Атина у то време била демократија, Перикле је, према чувеним речима историчара Тукидида, владао као њен „први човек.“ Тукидид је хероизовао Перикла као идеал демократског вође, супериоран у расуђивању, сасвим неискварен, и надмоћан у кроћењу превртљивог демоса. Али Перикле је такође био посвећен атинској империјалистичкој политици која је најзад навела Спарту да објави рат, како би зауставила непрестано атинско ширење противно интересима њених савезника. Тако је Спарта објавила 432. године још један „борбени поклич слободе“: овај пут са циљем ослобођења Хелена од тлачења „града-тиранина“, империјалне Атине. Перикле је такође, у то сам уверен, смислио слоган о Атини као о „највећем и најслободнијем граду“ да би се супротставио спартанским тврдњама. Под Периклом, „слобода“ је достигла свој пун опсег значења и трпела деформацију у своју супротност: оправдање империјалног угњетавања. ${ }^{7}$

$M u$ мислимо о перикловској Атини као о „Златном добу“ величине у погледу културе и хуманизма, добу које карактеришу Партенон, Фидијине скулптуре, Софоклове трагедије, Херодотова Историја и настанак Сократове филозофије. Атињани оног времена су „величину“ одређивали по запањујућим успесима у рату, империјалним ширењем без преседана и по неупоредивој слободи. Ипак, само тридесет година касније, после дугог и оштрог рата, Атина је капитулирала, изгладнела и исцрпљена. Поштеђена је уништења и поробљавања које је тако великодушно намењивала другима, али је изгубила своје царство, флоту и зидове. Како то историчар Ксенофонт саопштава, „,..почели су се разарати зидови, уз веселу пратњу свирачица на фрули, док су сви сматрали да овим даном почиње слобода Хеладе.“ Као што је то био случај тако често у каснијој историји, све до наших дана, и ово се показало обманом: ослобођење је ускоро уступило место још једном угњетавачком режиму, овај пут спартанском. ${ }^{8}$

Ово је велики оквир који одређује тему овог есеја. Допустите ми да сада изнесем нешто од садржаја, почевши од још једне асоцијације коју изазивају Есхилови Персијанци, и то не малим делом баш горе цитирани грчки бојни поклич на Саламини.

Грчко откриће слободе као политичке вредности

Управо је големо искуство победа над моћним персијским освајачем, које су мали грчки градови-државе постигли насупрот сваке вероватноће, било оно што је довело политичку вредност слободе у први план. Истина, као друштвена вредност, обележавајући статус слободног човека насупрот робу, слобода је била на цени још од појаве ропства и добро је посведочена већ у најранијим грчким записима. Али околности у раној Грчкој - или ма где другде у древном свету - нису охрабриле

\footnotetext{
${ }^{7}$ Тукидид о Периклу: II 65. Ратна пропаганда Спарте (ослобођење Хелена од тиранског града): Тhuc. II 8; cf. I 122, 124. Атина као највећи и најслободнији град: VI 89, 6; VII 69, 2 (в. ниже, нап. 33). О оба питања: Raaflaub 2004, глава 5.

${ }^{8}$ Xen. Hellenica (Грчка историја) II 2, 23 (прев. Милена Душанић). Атински приоритети у дефинисању „величине“: Boedeker и Raaflaub 1998, 1-10. О Перикловом добу: Samons 2007.
} 
развој политичког концепта слободе. ${ }^{9}$

У оквиру сопствених заједница, владајуће аристократе су тежиле одржању традиционалног степена моћи и међусобно се гложили око привилегија. Један од њих је чак могао да уграби прилику да узму сву моћ за себе, успостављајући оно што Грци зову тиранијом. Циљ његових аристократских противника није био повратак слободе - што је просто значило да њима није владао неко други, да нису били „неслободни“ - оно чему су они тежили била је моћ или једнакост међу себи равнима. Тако је, у супротстављању тиранији, истакнуто место добила вредност коју су раније сви узимали здраво за готово: једнакост, isonomia, буквално „исти ред“: једнакост пред законима или подједнака права, одатле једнако учешће у политици или политичка једнакост. Управо је овај израз, једнакост, употребљаван да опише постепено ширење политичких права на све грађане у демократији. Херодот каже да демократија носи најлепше од свих имена, isonomia, политичка једнакост. Слобода је ступила у нарочиту везу са демократијом тек касније, а израз ,једнакост говора“ (isegoria) остао је популаран чак и онда када су Грци измислили реч за „слободу говора“ (буквално „право да се каже све“, parrhesia). ${ }^{10}$

У односима између заједница у раној Грчкој ратови су били чести али краткотрајни и вођени углавном због спорне земље и плена. Освојене територије су интегрисане у област победника а не стављане под страну власт. Друго средство коришћено за повећање сфере утицаја једног града био је хегемонистички савез; њега је са посебним успехом примењивала Спарта у виду тзв. „Пелопонеског савеза.“ Такви системи савеза су наметали извесне војне обавезе својим члановима и чували превласт и одређен степен принуде за вођу (hegemon). Али то су биле лабаве организације, ограничене на заједничке походе о којима се одлучивало општим договором, остављајући на тај начин суверенитет чланова углавном нетакнутим. $^{11}$

Многе грчке државе у западној Анадолији, чији су становници названи Јоњанима, покорили су Персијанци средином VI века п.н.е. Пре тога, Грци, живећи далеко ван обзорја великих империја, једноставно нису навикли да очекују трајно потчињавање као последицу рата или склапања савеза. Лако је замислити, из свих наведених разлога, да је сусрет са Персијским царством био велики шок који је променио њихова гледишта и ставове заувек. У ствари, ако се то за једно царство може рећи, персијска владавина је била релативно бенигна - докле год су се поданици понашали онако како се од њих очекује. Морали су да плаћају порез и да дају трупе за краљеве ратове. Иначе су били углавном препуштени сами себи. Али су моћ, воља и реч краљева, његових намесника и оних којима је поверио власт над

\footnotetext{
${ }^{9}$ Недостатак концепта политичке слободе у античком свету: Raaflaub 2004, 4; 2009a, 50-51; у архајској Грчкој: 2003; 2004, глава 2.

${ }^{10}$ Најранија грчка уставна терминологија је била концентрисана на „ред“: еи-потіа (добар поредак), dysпотіа (лош поредак): Meier 1990a, 160-162. Модификован іso-компонентом: isonomia (једнак поредак, расподела, учешће; једнакост пред законима); такође isegoria (једнакост говора), isokratia (једнакост моћи); видети Vlastos 1953; Hdt. III 80, 6. О термину parrhesia (pan-rhesia, право да се све каже, слобода говора): Raaflaub 2004, 221-225. Демократија и слобода: ibid. глава 6.

${ }^{11}$ Ширење моћи у архајској Грчкој: Raaflaub 1994, 114-118. Пелопонески савез: Kagan 1969, 9-30.
} 
грчким градовима у Малој Азији, били апсолутни. На великом натпису уклесаном у степи близу своје престонице, Ксерксов отац Дарије је набројао народе који су били потчињени и закључио:

Каже краљ Дарије: „Ово су земље које су ми препуштене; вољом Ахурамазде [врховног божанства] били су моји поданици; доносили су ми данак; оно што сам им наложио, била ноћ или дан, учињено је.“ Каже краљ Дарије: „У овим земљама човека који ми је био веран сам богато наградио; онога који је био зао сам прописно казнио; вољом Ахурамазде ове су земље показале поштовање према мом закону; како сам им ја рекао, тако је и учињено.“ 12

То, наравно, није било оно на шта су Грци навикли. Они који су владали јонским Грцима уз персијску подршку, мада су били припадници локалне аристократије, сматрани су тиранима. Године 499. Јоњани су подигли устанак који је сломљен свега пет година касније. Град који је отпочео ову побуну, Милет, до тог времена политички и културно први у грчком свету, био је уништен а његови становници расељени. Атина је у почетку помагала овај устанак и тако навукла на себе персијски гнев. Поврх тога, године 490. Атињани и Спартанци су убили персијске гласнике који су захтевали „земљу и воду“, као знаке потчињавања, бацивши их у јаму и у бунар (као да су рекли: узмите сами земљу и воду за вашег краља!). ${ }^{13}$ Знали су шта могу да очекују од персијске освете ако буду побеђени. Године 480, када је Ксеркс напао Грчку са својом силном армијом, они и њихови најближи савезници су образовали језгро грчког савеза који му је пружио отпор. Они су се борили за опстанак колико и за независност. Али када су победили и размислили о свом подвигу, и када су упоредили одлике својих сопствених заједница са Персијским царством, нису могли а да не увиде кључне разлике између једне ауторитарне монархије и једне суштински слободне и егалитарне грчке заједнице. Био им је неопходан концепт који би све то изразио. И тако су буквално измислили „слободу“, као реч и као концепт. У току рата, позвали су у помоћ своје највише божанство, Зевса, у његовој традиционалној улози „Спаситеља“ (Soter). Након рата, преименовали су га у „Ослободиоца“ (Eleutherios). У песми која обележава једну од битака из 480, песник Пиндар слави Атину јер је „подигла бљештави темеље слободе“; године 478. исти песник је употребио по први пут именицу eleutheria, слобода. Грцима раније уопште није требала таква именица - а сада јесте! ${ }^{14}$

По ко зна који пут, историчар Херодот сажима оно што је најзначајније у живој приповести. Два спартанска изасланика, саопштава он, послати су у персијску престоницу да својим животима искупе злочин који је потчинила ьихова заједница убијајући персијске посланике. На путу, један персијски намесник им саветује да се

\footnotetext{
12 Персијска власт над Грцима: Briant 2002; Balcer 1995. Натпис Дарија у Бехистуну је објављен код Kenta 1953.

${ }^{13}$ О јонским тиранима: Graf 1985; Јонски устанак: Murray 1988; „земља и вода“: Khurt 1988. Персијски гласници: Hdt. VII 133.

${ }^{14}$ Eleutheria: Pind. Isth. VIII 10-16; уп. фраг. 77, Snell-Maehler. Откриће слободе од Зевса Спаситеља до Зевса Ослободиоца: Raaflaub 2004, глава 3.
} 
потчине краљу, постану његови пријатељи и искористе његову дарежљивост и спремност да награђује по заслузи, да на тај начин стекну моћну позицију међу Персијанцима. Спартанци су одговорили: „Савет који си нам дао није и за нас толико важан. Ти нам, наиме, саветујеш само оно што си искусио, а друго ти је непознато. Ти знаш, наиме, само за ропство а слободу ниси никада ни окусио и не знаш да ли је она слатка или не. Да си је, наиме, окусио не би нам саветовао да се за њу боримо само копљима него и секирама““ (прев. М. Арсенић). Грци нису разумели персијски концепт „вазала“ (bandaka); они су ову реч просто преводили као „роб“ (doulos). У њиховим очима, у поређењу са апсолутном моћи Великог краља, чак ни највећи достојанственик није ништа више од роба. ${ }^{15}$

\section{Рат, царство и демократија}

Победничка еуфорија убрзо је уступила место конфликту и супарништву. Циљеви Спарте и Атине након рата су се разликовали. Спартанци су веровали да је рат окончан и ускоро су се повукли из заједнички ратних напора. Атињани су страховали од још једног персијског покушаја инвазије и, подстицани од Јоњана који су се побунили против Персије, основали нови савез, чије је седиште било на острву Делу, одатле га зовемо „Делским савезом.“ Тамо су се савезници окупљали у скупштини да би доносили одлуке о заједничким подухватима. Они су или плаћали новчане доприносе у заједничку благајну или давали бродове за заједничке походе. Атина, најмоћнија чланица, била је и неоспорни вођа. Ипак, у почетку је савез деловао на принципима коју свим савезницима обезбеђивали известан степен једнакости. ${ }^{16}$

Кроз мање од две деценије, овај савез је постао нешто сасвим другачије и без преседана у грчком свету: Атинско царство. Опортунизам, атинске амбиције и недостатак пажње или активног учешћа од стране савезника су били главни чиниоци коју су довели до ове трансформације: било је јефтиније и лакше давати новац него бродове, те допуштати Атињанима да користе новац за изградњу и опремање флоте. Тако је Атина постала још моћнија а савезници слабији. Савез се ширио убеђивањем и принудом; покушаји да се Савез напусти третирани су као побуне и безобзирно гушени. Временом, седиште и благајна Савеза су пренети у Атину, скупштина савезника игнорисана а атинска народна скупштина је уместо ње доносила одлуке и законе за читав Савез. Као последица, јавило се све централизованије царство, којим су Атињани и њихова флота владали чврстом руком. ${ }^{17}$

У војном погледу, овакво стање је захтевало непрестану припремљеност за рат. У ствари, у периоду после Персијских ратова, Атина је водила војне походе

\footnotetext{
15 Спартански посланици: Hdt. VII 135. Највиши достојанственик као роб: види грчки превод писма краља Дарија сатрапу (намеснику) Гадати у Fornara 1983, 37, бр. 35: „Краљ краљева Дарије Хистаспов син, Гадати робу (doulos) своме овако говори...“ “За персијског „вазала“ (bandaka) видети Briant 2002, 324325.

${ }^{16}$ Од Делског савеза до Атинског царства: Meiggs 1972; Rhodes 1992.

${ }^{17}$ О Атинском царству, видети Meiggs 1972; Schuller 1974.
} 
током две од сваке три године. Током периода од седамдесет година, структура моћи која је контролисала приближно 200 заједница око Егејског мора и ван њега, држана је на окупу путем непрекидног војног ангажовања грађанског тела које никада није било веће од, рецимо, 50.000 људи. Тукидид је у потпуности свестан овог постигнућа. У чувеном Погребном говору, одржаном на државној сахрани оних који су пали у првој години Пелопонеског рата (431), он ставља у уста Перикла похвалу упућену трима генерацијама Атињана: прецима који су очували слободу (у Персијским ратовима), очевима који су створили царство властитом крвљу и знојем, те савременој генерацији која је ,још више у свему оснажила државу и снабдела је тако да сама може да задовољи своје потребе и у рату и у миру““ (II 36).

Две године касније, када су Атињани били погођени епидемијом и спартанским пустошењем њихове околине, Перикле је употребио хладније речи да поврати морал Атињана:

Знајте да Атина у целом свету ужива најславније име, зато што не попушта у невољама и што је у рат уложила и многобројне животе и труд и да сада има највећу силу која је икад, све до данашњег дана, постојала. Спомен на њену величину... треба да се заувек преда потомству: [А шта је то што ће потомство да памти?] Како смо ми, као Хелени, владали највећим бројем Хелена у највећим ратовима које смо водили против нашег непријатеља... како смо живели у једној држави која је у свему била најбогатија и највећа.

(II 64; прев. Душанка Обрадовић)

Поново, величина је одређена искључиво ратом, победама, жртвама ради заједничке моћи - отворено речено, одређена је количином крви по глави становника која је проливена за славу државе. А тај данак у крви био је врло висок. У једној јединој години, 460, само једна од десет фила (јединица грађанске организације) забележила је губитак од 177 људи (приближно 3,5 до 4,5\% свих одраслих људи), који су погинули у борбама на Кипру, у Египту, Феникији и Грчкој. У походу на Египат педесетих година V века, замишљеном као подршка једном устанку против персијског краља, изгубило је живот око 8000 грађана; приближно један од сваких седам одраслих грађана мушког пола. Најмање 10.000 је изгубљено у катастрофи на Сицилији 415-413, а 28.000 у читавом Пелопонеском рату, по чијем окончању је укупан број грађана пао на мање од половине предратног броја. ${ }^{18}$ Ако ове размере упоредимо са савременим државама разумећемо и значај тих цифара: оне далеко превазилазе чак и број погинулих у Другом светском рату.

Рат је играо огромну улогу у животу грађана. Сачувани извори на много начина илуструју и узбуђење и изразиту малодушност које су изазивале победе и неуспеси у рату. Атињани су били условљени, од детињства до старости, да о рату и о царству стеченом ратом, мисле као о нечему неопходном, корисном, чак и пожељном. На агори су, на пример, стајале три херме, стубови са главом бога Хермеса. Песма уклесана на њима прослављала је успех Атињана над Персијанцима

${ }^{18}$ Атински губици: Strauss 1986, 179-182; Hansen 1988, 14-28. 
у Тракији 476. године. ${ }^{19}$ Навешћу само два двостиха:

Ови нека стоје као споменик што је Атина подигла својим вођама, почаст за муком извојеване победе, заслужене делима ваљаним.

Они што долазе после нека читају и на овом споменику нек' нађу храброст, да би за част отаџбине с подједнаком храброшћу пошли у рат.

Порука се не може исказати јасније! Од младих грађана се очекивало да опонашају своје претке и да „за част отаџбине с подједнаком храброшћу пођу у рат!“ Управо је ово осећање, пре стотину година, одвукло Европу у Први светски рат.

Политички, Атинским царством су колективно управљали грађани грададржаве или, како су то сами Грци схватали, државе грађана. „Град чине људи!“ узвикује један атински војсковођа код Тукидида. Надаље, у непосредној вези са формирањем њиховог царства, Атињани су развили најрадикалнију демократију замисливу у древном свету, прву у светској историји. ${ }^{20}$ Пошто царства углавном стварају и њима управљају монарси (сетите се Кира, Александра, Карла Великог), понекад аристократије (Рим), овај случај је на сваки начин изузетан.

Сами Атињани су били потпуно свесни везе између царства и демократије. Око 430. један анонимни противник демократије покушао је да објасни један упадљив парадокс: принципи који подупиру демократију у његовом граду су потпуно смислени, иако свака паметна - што ће рећи: аристократска - особа зна да је демократија један сасвим апсурдан систем јер даје моћ „будалама“ тј. сиромашним, необразованим, ирационалним и морално инфериорним нижим класама. Чак и тако, он признаје:

Правично је за сиромашне и обичне људе (demos) у Атини да имају више од оних доброг порекла и богатих, јер су обични људи ти који дају посаде за бродове и омогућују граду да буде моћан... у много већој мери него хоплити, људи доброг порекла и, уопште, добре класе. Кад је то већ тако, чини се да је правично свима отворити приступ јавним функцијама... и да се сваком грађанину допусти да говори, ако жели. ${ }^{21}$

Ова изјава, која повезује војну способност грађана са њиховим политичким правима, нуди једно прагматично оправдање демократије. Приближно у исто време, Херодот је радио на својој монументалној историји Персијских ратова. Коментаришући атинске победе након протеривања тирана у позном VI веку, он наглашава значај једнакости и слободе:

\footnotetext{
${ }^{19}$ Есхин III 183-185 („Ејонски епиграми“, прев. C, Adams [Loeb Classical Library]). О улози рата у Атини, видети Meier 1990b; Hanson 2001; Raaflaub 2001.

${ }^{20}$ Империја и демократија: Raaflaub et al. 2007, глава 5. „Град чине људи“ - Thuc. VII 76, 7. О атинској демократији уопште, видети Bleicken 1994; Hansen 1999.

${ }^{21}$ Pseudo-Xenophon, Атински устав I 2 (преведено код Bowersock-a 1968; Moor-a 1975; Osborne-a 2004).
} 
И Атина се тада јако оснажи. Јасно је... каква преимућства има слобода. Док су Атињани били под влашћу тирана, нису били јачи у рату ни од једног од својих суседа; а кад су се опростили од тирана, постали су први међу њима. Сасвим је разумљиво да се, док су били робови, нису трудили да буду добри војници, јер би то ишло на корист насилнику; напротив, када су постали слободни, и кад се радило о њиховом добру, сваки је дао све од себе.

(V 78; прев. М. Арсенић)

Оправдање кроз успех било је, у ствари, најјачи аргумент у прилог демократије. А успех демократије био је оличен, врло моћно и упадљиво, кроз њено царство. Допадало се то нама или не: прво царство у историји Запада створио је један демократски град. Још један интересантан парадокс!

Идеологија која је правдала атинско вођство и владавину се заснивала на тврдњи да је Атина дала лавовски допринос спасавању свих у Хелади, тако што је спречила поробљавање од стране Персијанаца, и на обећању да ће Атина наставити са одбраном грчке слободе од Персије и тирана које су Персијанци устоличили. У обема тврдњама, идеологија се у суштини заснивала на слободи.

\section{Слобода и империјализам}

Године 432, када су Спарта и њени савезници разматрали да ли да крену оружјем против Атине, Тукидид саопштава да су се атински посланици обратили скупштини. Атина није учинила ништа, тврдили су они, што би у датим околностима било непримерено или што неко други, укључујући и Спарту, не би урадио на њеном месту. Конкретно, уздизање Атине било је сасвим заслужено и потпуно оправдано јер су на Маратону сами потукли Персијанце а за победу код Саламине су дали највише бродова и најспособнијег заповедника, и јер су показали непоколебљиву храброст. Жртвовали су сопствени град и ставили све на коцку ради општег добра Хеладе. Да су одлучили другачије и нагодили се с Персијанцима, Хелада би била осуђена на пропаст. Две појединости заслужују више пажње: тврдња Атине да је спасла слободу Хеладе, и политичке и идеолошке консеквенце које су извучене из те тврдње.

Атињани су често истицали своје заслуге у Персијским ратовима - у толикој мери да је то постало „стара прича“ и да је људима дојадило да је слушају све време. $^{22}$ У антици је било опште прихваћено да доброчинство значи и обавезу од стране онога ко га прима. Стога је и Атина, с добрим разлозима, очекивала да буде слављена и поштована за своје заслуге. Како је из Персијских ратова изашла као велика војна сила, њен захтев за вођством је био подједнако неоспоран и у „Делском савезу.“ Проблеми су се јавили тек онда када је Атина ово оправдање проширила да

\footnotetext{
22 „Стара прича“: на пр. Thuc. I 73: „Што се, међутим, тиче Персијских ратова и свих оних догађаја које и сами знате, потребно је да се и они спомену, иако то може бити и досадно, будући да се стално истичу у први план.“ VI 89: „Ни ми, наиме, са наше стране, нећемо се користити лепим речима: како с правом владамо зато што смо однели победу над Персијанцима, или да смо дошли да вас нападнемо зато што смо претрпели неку неправду нудећи вам у једном подужем говору нешто у шта нећете веровати““ (прев. Д. Обрадовић).
} 
обухвати не само хегемонију у савезу, већ и власт над царством. Употреба заслуга за слободу да се оправда империјална власт над ослобођенима - то је изазвало отпор, и то све више како су Атињани утврђивали и ширили своју власт. То је за последицу имало да Атина буде обележена као град-тиранин. На тој основи је позив за ослобођење Хелена постао спартански „бојни поклич за слободу“ у Пелопонеском рату.

Херодот је у потпуности био свестан овог проблема. На једном месту у својој Историји, када се Ксеркс спрема да пође у инвазију Грчке, он пише:

Морам да изразим једно мишљење које многима неће бити по вољи... Да су се, наиме, Атињани из страха пред опасношћу повукли из своје земље, или да су ce, не повукавши се, предали Ксерксу, не би нико ни покушао да се на мору супротстави краљу. А да се Ксерксу нико није супротставио на мору, [Персијанци би лако покорили и остатак Грчке]... А овако је сигурно да није нимало погрешио онај ко је рекао да су Атињани спасли Хеладу... Својом одлуком да Хелада остане и даље слободна, они су охрабрили и све остале Хелене који нису признали персијску власт...

(VI 139; прев. М. Арсенић)

Дакле, Атињани јесу били спасиоци грчке слободе. Херодот наглашава овај закључак још снажније на једном каснијем месту, када се 479. персијски војсковођа Мардоније, који је у Грчкој остао са великом армијом, спремао да настави копнени поход. Он сада покушава да подели непријатеља и придобије Атињане на персијску страну. Он им нуди повољан уговор о савезу и грчку територију по избору да њоме владају. Атињани тако имају прилику да очувају сопствену слободу и да се прошире на штету својих савезника.

Спартанци, озбиљно узнемирени, преклињали су их да не прихвате ову понуду, позивајући се на атинску властиту идеологију: „Уосталом, били би ужасно да сви Хелени постану робови кривицом вас Атињана, који се с правом поносите да сте одувек помагали многим народима да постану слободни.“ (VIII 142)

Атињани су одговорили персијском изасланику: „Знамо то и сами да Ксеркс има неколико пута већу војску него ми... Али наша љубав према слободи је толика да ћемо се бранити докле год будемо могли. Немој ни покушавати да нас наговориш да склопимо мир са варварином, јер те нећемо послушати. А сад јави Мардонију да док буде Сунце ишло истим путем којим и сада иде, нећемо се никада помирити са Ксерксом..."(VIII 143)

Спартански посланицима су рекли: „Нема на свету тог злата нити тако лепе и богате земље чиме би нам се могло платити да добровољно пређемо на страну Персијанаца и да помогнемо да Хелада падне у ропство.“ Зашто? Због заједничке обавезе да се освети персијско уништавање грчких храмова и због грчког јединства кроз сродство, језик и обичаје. „Било би срамота да Атињани буду издајници свега тога.“(VIII 144; прев. М. Арсенић)

И заиста: било је срамота! Контраст је шокантан и смишљен: у тренутку када је Херодот ово писао, Атина јесте склопила мир са Персијанцима и чак је, у 
раној фази Пелопонеског рата, тражила персијску помоћ против Спарте. ${ }^{23}$ Ослободилац је постао угњетавач, спаситељ Грчке је постао тиранин.

Како су се сами Атињани носили са негативним нуспојавама властите политике? Уствари, и нису били нарочито забринути. Њихово је доба, чини се, било такво да су прагматизам и реализам однели превагу над моралним дилемама, доба у којем су доминирали оптимизам и готово неограничено уверење у људске могућности и напредак. Заснивајући став на пажљивом разматрању расположивих ресурса, Перикле је сматрао да се чак и велики рат може прорачунати и спровести са сигурношћу и поуздањем. ${ }^{24}$ Његови суграђани су достигли историјски врхунац, опијени узбуђењем које је донела моћ. Ранији успеси су обликовали њихов колективни или „национални“ карактер: њихов заштитни знак био је „чинити много“ (polypragmosyne); они су постали крајњи „активисти“ и интервенционисти, сушта супротност спорих, опрезних и нефлексибилних Спартанаца. Они су увек били тамо негде у покушају да стекну даље предности, брзи и да се одлуче и да делају, надмоћно самоуверени и упорни: као што би то њихови највећи непријатељи, Коринћани, рекли: „За њих је само онда празник када обављају своју дужност и зато сматрају да је потпуно мировање већа несрећа него напоран рад. Једном речју... они ни сами немају мира нити друге људе пуштају на миру“ (прев. Д. Обрадовић). ${ }^{25}$

Како то Аристофанова представа Птиие показује, изградња царства је постала нешто тако природно за њих, да два атинска грађанина, бежећи од муке парничења у граду затрованом политиком и тражећи уточиште у идиличном свету птица, убрзо наводе своје домаћине да створе царство у ваздуху. Ово им омогућава да загосподаре не само људима, већ и боговима. ${ }^{26}$ На крају, њихов вођа, један сасвим просечан Атињанин, приморава Зевса да му преда госпођицу Царство (Basileia), коју одмах затим ожени, испуњавајући свој највећи сан - за Сигмунда Фројда ово би било права гозба! Насупрот томе, неки пасиван, неангажован грађанин је у суштини био бескористан за своју заједницу.

Надаље, Спартанци су били у слабој моралној позицији да би могли да критикују Атињане. У једном ранијем уговору, сами су прихватили да они који живе у атинској сфери утицаја нису ничија брига до атинска. Упркос притужбама спартанских савезника, Атињани су били одлучни у ставу да нису прекршили уговор, а касније су наводно и Спартанци прихватили овај став. Више пута у току рата, Спартанци су били спремни да склопе мир на темељу status quo, занемарујући и своје савезнике и слободу Хелена. Да се само Атина сложила да одустане од економске блокаде против суседне Мегаре, читав рат се могао избећи. Наглашавајући ове аспекте, Тукидид открива спартански бојни поклич за слободу

\footnotetext{
${ }^{23}$ Мир са Персијом: Bengston 1975, 64-69 (бр. 152); Fornara 1983, 97-103 (бр. 95); Lewis 1992a, 121-127. Тражење помоћи од Персије: Lewis 1992b, 421.

24 Thuc. I 140-144; II 13. О атинској „свести о властитим способностима“: Meier 1990a, 186-221.

${ }^{25}$ О ,активизму, чињењу много тога“ (polypragmosyne) као о типичној црти атинског колективног карактера, видети Thuc. I 70. О атинском концепту активних и пасивних (apragmon), видети Тhuc. II 40, 61, 64; Carter 1986; Raaflaub 1994; Christ 2006; Demont 2009.

${ }^{26}$ О страсти за изградњом царства у Аристофановим Птицама, видети, на пример, Konstan 1995, 29-44; ibid. 1997.
} 
као средство пропаганде. Једино је важан био непосредан спартански интерес. У овом погледу, Спарта се није показала ништа бољом од Атине. ${ }^{27}$

И тако су Атињани следили двоструку стратегију. Споља, они су заузели став који су бранили атински посланици у Спарти: Атина није учинила ништа лоше и морала је да брани властиту слободу. Понудили су да прихвате посредовање и одбили да прихвате захтеве изнете у виду ултиматума. Учинити тако, инсистирао је Перикле, било би знак покорности, неспојиво са чашћу слободног човека или слободног града: „Јер, ако се и највећи и најмањи захтеви равноправних партнера суседима не постављају позивањем на правду, него наређењем, онда се ради о ропству“ (Thuc. I 141; прев. Д. Обрадовић). Занимљиво је да се трагички песник Еурипид, иако често критичан према политици свога града и његовим вођама, изгледа слаже. Негде у то време, написао је драму Хераклова деца, која исказује исту поруку. Гласнику Еуристеја, Херакловог смртног непријатеља, који захтева изручење деце овог хероја, која су потражила уточиште на атинској територији, и који то чини у облику ултиматума, претећи ратом у случају одбијања, атински представник одговара овако:

\footnotetext{
Јер допустим ли, олтар да ми странац тај Сад пљени, држат ћу у земљи слободној Да нијесам и од аргивског да страха ја Те прибјегаре издах.
}

(243-246; уп. 284-287; прев. К. Рац, Н. Мајнарић)

У свом говору на сахрани палих Атињана, Перикле наглашава да „ми своје пријатеље стичемо више чинећи услуге него примајући их од других... А ми смо једини који другима користимо, и то не из неког рачуна, него из уверења да смо слободни људи“ (Thuc. II 40). Ма каква била права истина о овој ствари, у том тренутку Атињани су свакако били уверени да је њихов циљ праведан и да ће стога и богови бити на њиховој страни.

Са друге стране, Атињани су спољашњој критици тиранске владавине свог града над империјом супротставили властиту идеологију слободе. Ако би били притиснути у полемици, чак су и атински лидери прихватали примедбу о тиранији. Тако је учинио и Перикле у свом последњем говору: „Јер власт коју ви сада држите јесте тиранска власт, а изгледа да се она задобија неправдом; велика је, међутим, опасност ако се она испусти из руку“ (Thuc. II 63; уп. III 37; прев. Д. Обрадовић). Али једно позитивније гледиште било је много боље. Тако је говорио Перикле у говору који сам цитирао раније: Ми имамо највеће име јер смо задобили највећу моћ од свих грчких градова икада, задобили смо највише победа и успоставили своју власт над невиђеним бројем градова. „И није нам потребно да нас Хомер у песми слави, нити неки други песник - који би, додуше, могао да нам пружи тренутно уживање, али би оваквом приказивању догађаја после могла наудити истина... За

\footnotetext{
${ }^{27}$ Мировни уговор из 446: Bengston 1975, 74-75 (бр. 156). Спартанско признање: Thuc. VII 18; мировне понуде: IV 15-41; Мегара: I 139. Спартански бојни поклич за слободу као пропаганда: Raaflaub 2004, 193 202.
} 
своје смеле подвиге отворили смо пут у свим земљама и на свим морима и свуда поставили непролазне споменике добра и зла“ (II 41; прев. Д. Обрадовић).

Лако је разумети тврдњу да је један град највећи. Али Перикле уједно инсистира да су Атина у његово време ,још више у свему оснажили“ и да је „снабдевена тако да сама може да задовољи своје потребе и у рату и у миру“ (II 36, претходно цитирано). Атинска представа о себи је укључивала потпуну самодовољност (autarkeia). ${ }^{28}$ Како ово може бити истина?

Већина античких аутора се слаже да је самодовољност идеал који могу да достигну само богови, мудраци и они који немају никаквих потреба. Чак се и заједница ослања на друге да задовољи сопствене потребе. А ипак, према Тукидидовом Периклу, Атињани су превазишли таква ограничења на два начина. Један је то да појединац налази у овом граду најбоље услове за слободан развој своје личности, у правцу свестране и самосталне врлине ради претварања у самодовољну особу (soma autarkes). ${ }^{29}$ И као заједница, такође, Атина зависи од једне веће заједнице, спољног света, чак и изван граница њеног царства, али је свеједно самодовољна јер је у стању да својом силом осигура да све њене потребе буду трајно задовољене. Тако је концепт самодовољности (autarkeia) сјајно искоришћен за тријумфалну карактеризацију једне изузетне, готово надљудске, и буквално апсолутне способности за самоодређењем коју је само један град успео да достигне и коју је у суперлативном облику „најсамодовољнијег града“ (autarkestate polis), обухватио атинску величину, власт и потпуну независност.

Две примедбе су овде на месту. Таква монополизација самодовољности од стране највећег града нужно је значила озбиљна ограничења наметнута потчињеним градовима. Довољно је да се сетимо концентрисања трговине у Егејском мору на Пиреј и атинске контроле прекоморске трговине и саобраћаја, која је наглашена у озлоглашеној блокади наметнутој суседној Мегари. ${ }^{30}$ Као друго, као што се могло и очекивати а што су потврдила оба историчара савремена овим догађајима, ова атинска тврдња није прихваћена без оспоравања. Сам Тукидид примећује, у свом опису велике пошасти која је опустошила Атину у раној фази рата, да се ни једна самодовољна особа (ни једна soma autarkes) нигде није могла видети. ${ }^{31}$ Пошаст, чији је опис ради већег ефекта смештен одмах уз Погребни говор и Периклове неумерене похвале демократске Атине као идеалне заједнице, открива испразност овог идеала. Суочена са ужасном кризом, танка глазура друштвених односа и доброг грађанства је спрана а неогољена људска животиња се појављује. Кроз одговор једног мудраца (Солон) најбогатијем човеку на свету (лидијски краљ Крез, који је ушао у изреку), Херодот истиче да:

\footnotetext{
${ }^{28}$ О самодовољности као о политичком концепту, видети Raaflaub 2004, 184-187.

${ }^{29}$ Thuc. II 41 (Перикле): „Чини ми се да је сваки човек међу нама способан да са извесном лакоћом и окретношћу ради све могуће послове; и да сам себи буде потпуно довољан (soma autarkes).“

${ }^{30}$ O „мегарској псефизми““: Thuc. I 67; Plut. Per. 29 и даље; de Ste. Croix 1972, 225 и даље; Hornblower 1991, 110-112. О Пиреју и његовој улози као центра егејске трговине: Garland 1987; Raaflaub 1998, 22-26.

31 Thuc. II 51: „А показало се да ниједан организам, био он снажан или слаб, није сам по себи довољан да се одупре“ (прев. Д. Обрадовић); буквално „није био самодовљног тела или особе, никакве soтa autarkes“.
} 
Човек не може да има све што зажели, као што ниједна земља нема све што јој треба... Она која од њих има на расположењу већину потрепштина, та је земља најбоља. А тако и једно човечије тело није само по себи довољно. С једне стране има што му је потребно, а с друге оскудева у нечему. Кад неко од људи проживи у сваком обиљу и задовољству и умре лепом смрћу, тај је достојан... да носи назив срећна човека.

(I 32; прев. М. Арсенић)

Попут Тукидида, и Херодот наглашава да ни једна особа и ни једна земља не могу бити самодовољни. Такво директно оспоравање потврђује аутентичност Периклове изузетне тврдње.

Најзад, не изненађује да су Атињани свој град такође спомињали и као најслободнији од свих. Песник псеудо-есхиловске трагедије Оковани прометеј, можда писане негде у ово време (око 430), допушта једном од ликова да каже: „Све тешко ти је осим власти над бозима, јер осим Дива нико није слободан“" (49-50; прев. М. Ђурић). ${ }^{32}$ Другим речима, само је краљ богова истински слободан! Слично је и са Атињанима: њихова моћ и власт над другима гарантовала је њихову слободу, унутар и изван њихове заједнице. Ипак, они су отишли даље за један пресудан корак. Они су спојили свој локални облик власти (демократија) са својом спољашњом влашћу (царство) да би створили свеобухватан „надконцепт“ моћи и власти, и онда овај повезали са слободом. Атински демос, владајући преко демократије Атином и преко Атине империјом, уживао је највећу, апсолутну слободу. Овај концепт се могао изразити само путем суперлатива, „најслободнији град“, који код Тукидида користе двојица водећих Атињана. ${ }^{33}$

Објаве нису биле довољне. Управо у ово време, Атињани су подигли на својој агори величанствени нови трем (stoa), који су улепшали богињама победе (Nikai) и посветили Зевсу Ослободиоцу, божанству које је помогло да се спасе слобода Грчке у Персијским ратовима. ${ }^{34}$ Тешко да се може и замислити већи акт пркоса. У исто време када су је непријатељи жигосали као град-тиранин а Спарта припремала рат за ослобођење Хелена, Атина се ставила под заштиту Зевса Ослободиоца и у овој грађевини симболично представила своју поносу тврдњу, засновану управо на својој владавини над Хеленима, да је она најслободнији, највећи и најсамодовољнији град.

Поново, несумњиво да је таква монополизација слободе од стране владајуће силе још јасније показала „поробљавање“ осталих - Атина је уствари навукла ципеле персијског краља - и бар песник Еурипид није оклевао да прикаже на сцени последице атинске империјалне политике у веома трагичној представи, Тројанке.

\footnotetext{
32 О могућем датуму ове представе: Griffith 1983, 31-35.

${ }^{33}$ Атина као најслободнији град (polis eleutherotate): Thuc. VII 68 [Никија]: „Подсећао их је на отаџбину у којој владају највеће слободе и на свакодневни живот без икакве присиле за све који у њој живе.“ VI 89 [Алкибијад]: „А ми смо стајали на челу целог народа и сматрали да је право да сачувамо овај облик владавина под којим је држава достигла своју највећу величину и слободу (megiste kai eleutherotate) и који смо наследили...“ (прев. Д. Обрадовић).

${ }^{34}$ Стоа Зевса Ослободиоца: Travlos 1971, 527-533; Camp 1986, 105-107.
} 
Нити можемо да заборавимо да су 404. ти исти Атињани, поражени и глађу натерани да се предају, како то Ксенофонт пише, „мислили су да се не могу спасти да не доживе оно што су сами чинили, и то не као казну, већ су из обести злостављали мале градове, само зато што су били савезници других“ (Hell. II 2, 10; прев. Милена Душанић).

\section{Закључак}

Укратко, дакле, Атина, славна колевка једне од највећих епоха културног уздизања у људској историји, спасилац грчке слободе у Персијским ратовима, творац демократије, и утемељитељ система политичких вредности који још увек доминира и нашим животима данас (слобода и једнакост, пре свих) - та иста Атина је показала како се ове вредности могу изопачити: претварајући вођство једног слободног света у царство, намећући демократију другима како би служила њеном властитом интересу (што је аспект који нисам разматрао на овом месту), и користећи слободу као изговор за искоришћавање и угњетавање. Верујем да није ни потребно наглашавати колико је све ово изузетно садржајно и за наше властито време. $^{35}$ Заиста вреди размишљати о античкој историји!

С енглеског превео Немања Вујчић

\section{Литература:}

Balcer, J. M., The Persian Conquest of the Greeks 545 - 450 BC, Konstanz 1995.

Bengston, H., (ed.), Die Staatsverträge des Altertums II: Die Verträge der griechisch-römischen Welt von 700 bis 338 v. Chr., München 1975. ${ }^{2}$

Bleicken, J., Die athenische Demokratie, Paderborn 1994. ${ }^{2}$

Boedeker, D., Raaflaub, K., (edd.), Democracy, Empire and the Arts in Fifth-Century Athens, Cambridge MA 1998.

Bowersock, G. W., Pseudo-Xenophon, Constitution of Athenians, y: Marchant, E. C., (ed.), Xenophon, VII: Scripta Minora, London - Cambridge MA 1971, 459 и даље.

Briant, P., From Cyrus to Alexander: A History of the Persian Empire, Winona Lake IN 2002.

Brock, R., Did the Athenian Empire Promote Democracy?, y: Ma et al., 2009, 149-166.

Camp, J. M., The Athenian Agora, London 1986.

Carter, L. B., The Quiet Athenian, Oxford 1986.

Cartledge, P., The Effects of the Peloponnesian (Athenian) War on Athenian and Spartan Societies, y: McCann, Strauss 2001, 104-123.

Christ, M. R., The Bad Citizen in Classical Athens, Cambridge 2006.

Demont, P., La cité grecque archaïque et classique et l'idéal de tranquillité, Paris 2009.

\footnotetext{
${ }^{35}$ Наметање демократије као империјално средство: Meiggs 1972, 208-212; Sculler 1974, 82-98; Brock 2009; Raaflaub 2009b, 105-106.
} 
Fornara, C. W., Archaic Times to the End of the Peloponnesian War. Translated Documents of Greece and Rome I, Cambridge 1983. ${ }^{2}$

Freeman, K., Ancilla to the Pre-Socratic Philosophers: A Complete Translations to the Fragments in Diels, Fragmente der Vorsokratiker, Cambridge MA 1948.

Garland, R., The Piraeus from the Fifth to the First Century B.C., London 1987.

Graf, D., Greek Tyrants and Achaemenid Politics, y: Eadie, J. W., Ober, J., (edd.), The Craft of the Ancient Historian: Essays in Honor of Chester G. Starr, Lanham Md. 1985, 79-123.

Griffith, M., (ed.), Aeschylus, Prometheus Bound, Cambridge 1983.

Hall, E., (ed.), Aeschylus, Persians. Ed. With an Introd., Trans., and Comm., Warminster 1996.

Hansen, M. H., Three Studies in Athenian Demography, Copenhagen 1988.

Hansen, M. H., The Athenian Democracy in the Age of Demosthenes, Norman OK 1999.

Hanson, V. D., Democratic Warfare. Ancient and Modern, y: McCann, Strauss 2001, 3-33.

Hornblower, S., A Commentary of Thucydides I, Oxford 1991.

Kagan, D., The Outbreak of the Peloponnesian War, Ithaca NY 1969.

Kent, R. G., Old Persian: Grammar, Texts, Lexicon, New Haven $1953 .^{2}$

Kirk, G. S., Raven, J. E., Schofield, M., The Presocratic Philosophers: A Critical History with the Selected Texts, Cambridge $1983 .^{2}$

Konstan, D., Greek Comedy and Ideology, New York - Oxford 1995.

Konstan, D., The Greek Polis and Its Negations: Versions of Utopia in Aristophanes' Birds, y: Dobrov, G. D., (ed.), The City as a Comedy, Chapel Hill 1997, 3-22.

Khurt, A., Earth and Water, y: Khurt, A., Sancisi-Weerdenburg, H., (edd.), Achaemenid History III: Method and Theory, Leiden 1988, 87-99.

Lewis, D., M., The Archidamian War, y: Cambridge Ancient History V, Cambridge 1992a², 370-432.

Lewis, D. M., The Thirty Year's Peace, y: Cambridge Ancient History V, Cambridge 1992b 2, 121146.

Ma, J., Papazarkadas, N., Parker, R., (edd.), Interpreting the Athenian Empire, London 2009.

McCann, D. R., Strauss, B. S., (edd.), War and Democracy: A Comparative Study of the Korean War and the Peloponnesian War, Armonk NY 2001.

McPherson, J. M., Battle Cry of Freedom: The Civil War Era, New York 1988.

Meier, Ch., Die politische Kunst der griechischen Tragödie, München 1988. (енг. превод 1993.)

Meier, Ch., The Greek Discovery of Politics, прев. D. McLintock, Cambridge MA 1990a.

Meier, Ch., Die Rolle des Krieges im klassischen Athen, Historische Zeitschrift 251 (1990b), 555605.

Meier, Ch., The Political Art of Greek Tragedy, прев. A. Webber, Baltimore 1993.

Meiggs, R., The Athenian Empire, Oxford 1972.

Moore, J. M., (ed.), Aristotle and Xenophon on Democracy and Oligarchy, Berkley 1975.

Murray, O., The Ionian Revolt, y: Cambridge Ancient History IV, Cambridge 1988. ${ }^{2}$, 461-490.

Osborne, R., The Old Oligarch: Pseudo-Xenophon's Constitution of Athenians. Introd., Trans., Comm., Lactor 2004. ${ }^{2}$.

Raaflaub, K., Politische Denken im Zeitalter Athens, y: Fetscher, I., Münkler, H., (edd.), Pipers Handbuch der politischen Ideen I: Frühe Hochkulturen und europäische Antike, München 1988, 273-368.

Raaflaub, K., Democracy, Power and Imperialism in Fifth-Century Athens, y: Euben, J. P., Wallach, J. R., Ober, J., (edd.), Athenian Political Thought and the Reconstruction of the American 
Democracy, Ithaca NY 1994, 103-146.

Raaflaub, K., The Transformation of Athens in the Fifth Century, y: Boedeker, Raaflaub 1998, 1341, 348-357.

Raaflaub, K., Father of All, Destroyer of All: War in the Late Fifth-Century Athenian Discourse and Ideology, y: McCann, Strauss 2001, 307-356.

Raaflaub, K., Freedom for the Messenians? A Note on the Impact of Slavery and Helotige on the Greek Concept of Freedom, y: Luraghi, N., Alcock, S., (edd.), Helots and Their Masters in Laconia and Messenia: Histories, Ideologies, Structures, Washington DC 2003, 169-190.

Raaflaub, K., The Discovery of Freedom in the Ancient Greece, Chicago 2004.

Raaflaub, K., Early Greek Political Thought in Its Mediterranean Context, y: Balot, R., (ed.), A Companion to Greek and Roman Political Thought, Malden MA - Oxford 2009a, 37-56.

Raaflaub, K., Learning from the Enemy: Athenian and Persian Instruments of Empire, y: Ma et al. (edd.) 2009, 89-124.

Raaflaub, K., Ober, J., Wallace, R. W., Origins of Democracy in Ancient Greece (са поглављима које су написали P. Cartledge и C. Ferrar), Berkley 2007.

Rhodes, P. J., The Delian League to 449 B.C., y: Cambridge Ancient History V, Cambridge 1992. ${ }^{2}$, 34-61.

Ste. Croix, G. E. M. de, The Origins of Peloponnesian War, London - Ithaca NY 1972.

Samons II, L. J., (ed.), The Cambridge Companion to the Age of Pericles, Cambridge 2007.

Schuller, W., Die Herrschaft der Athener im Ersten Attischen Seebund, Berlin 1974.

Strauss, B. S., Athens after the Peloponnesian War, Ithaca NY 1986.

Travlos, J., Pictorial Dictionary of Ancient Athenians, New York 1971.

Vlastos, G., Isonomia, American Journal of Philology 74 (1953), 337-366 (прештампано y: Vlastos, G., Studies in Greek Philosophy I, 89-111). 


\title{
KRIEG IST ALLER DINGE VATER: DIE POLITIK DES KRIEGES, IMPERIUMS UND DER FREIHEIT IN DEMOKRATISCHEN ATHEN
}

\begin{abstract}
Zusammenfassung
Athens „goldenes Zeitalter“ verkörpert aus unserer modern Sicht eine Epoche der Größe und Blüte in Kultur und Humanismus. Dafür zeugen uns der Parthenon, Phidias’ Skulpturen, Sophokles’ Tragödien, Aristophanes’ Komödien, Thukydides’ Geschichtswerk und die Anfänge sokratischer Philosophie. Die Zeitgenossen dagegen verbanden „Größe“ offenbar nur selten mit kulturellern Leistungen, sonder sahen sie als Resultat bemerkenswerter kriegerischer Erfolge, präzedenzloser Macht und Herrschaft und grenzenloser Freiheit, errungen von Bürgern, die aufgrund einer tief-prägenden bürgerlichen Ideologie ihre Pflicht in der Wahrung und Vergrößerung der militärischen und politischen Macht ihrer Gemeinde sahen. Athen war das erste griechischen Staatswesen, das ein Seereich geschaffen und das Prinzip der Demokratie so weit verwirklicht hatte, wie es damals überhaupt denkbar war. Herrschaft nach außen und Demokratie im Innern bedingten sich gegenseitig. Das Engagement der Bürger in ihrer Gemeinde war einmalig in der Weltgeschichte; das Maß an Macht und Freiheit, das sie genossen, blieb danach während mehr als zwei Jahrtausenden unerreichbar. Aber ausgehungert und erschöpft war dieses selbe Athen fünfundzwanzig Jahre nach Perikles' Tod gezwungen, der Krieg verloren zu geben und wäre beinahe zerstört worden. Dieser Beitrag lotet die Spannungen und Widersprüche aus, die in Athens Kriegs-, Herrschaftsund Freiheits-Politik und deren ideologischer Untermauerung und engen Verbindungen zur Demokratie liegen - Themen, die zeitlose Bedeutung haben und unsere eigene Zeit besonders ansprechen.
\end{abstract}

Schlüsselwörter: Krieg in der Antike, klassisches Athen, Perikles, Imperialismus, Demokratie, Freiheit. 